\title{
A VILÁG DOLGAIRÓL BESZÉLGET EL VELÜNK BEREND T. IVÁN
}

Rövid reflexiók sokaságát közli Berend T. Iván Élj érdekes időkben! címen magyarul megjelenő kötete, amelynek müfaját talán legkönnyebb úgy elkönyvelni, mint beszélgetéskezdeményt, százhúsznál több témában, személyes hangvétellel, informatív módon. Az utóbbi években írt jegyzetek magáról a szerzőről bizonyos értelemben még annál is többet árulnak el, mint történettudományi életmüvének eddig kiadott harmincöt kötete, hiszen ez alkalommal spontán véleménynyilvánítások sokaságát olvashatjuk a legkülönbözőbb kulturális, társadalmi és politikai fejleményekkel kapcsolatban, s ezekböl, ezek mögül sejlenek fel egy markáns szellemi arculat konzisztens vonásai.

A nagy tekintélyü történész, akadémikus, az MTA kritikus időkben volt elnöke világot járt ember és sokrétüen müvelt elme, aki legyen szó bármiről, azt történeti kontextusba helyezi, és tanári mivoltának megfelelően kristályos világossággal fogalmaz. Az elmúlt öt év feljegyzései nyomán így együtt kalandozunk térben és időben. Úti és olvasmányélményekhez, aktuális hírekhez és felfakadt emlékekhez kapcsolódóan szóba kerül a Föld számos országa és települése: az otthont adó Budapesten és Los Angelesen (és az európai reminiszcenciákat is ébresztő hipermodern Seattle-n) túlmenően a nagy múltján túllépő Dániától a csodálatosan megújhodó Írországon át a reménytelenül megrekedt Moldován keresztül a forradalmi illúziókat kergető Dél-Amerikáig.

Az érzelmileg gazdagon színezett intellektuális élmények alkalmasint klaszszikus müvekhez kötődnek (Balzachoz, Csehovhoz, Cervanteshez, bizonyítékául annak, hogy a szerző valóra váltotta sokak elvetélt vágyát, és módot talált emlékezetes könyvei újraolvasására), ám sủrün új irodalmi fejleményekre reagálnak (kortárs magyar írók közvetlen megszólításának formájában is). Megragadó filmek, felemelő koncertélmények, rendszeresen felkeresett képzőmüvészeti kiállítások mind feltűnnek az érzékletes beszámolókban - szintúgy átszürve a szerző jellegzetes értékvilágán. Berend Iván generációs eszmélésének időszakában, az 1940-es évek második felében Lukács György polgári humanizmusként címkézte (egyszerre méltányolta és kommunista radikalizmussal bírálta) ennek a világlátásnak a II. világháború utáni előképét, amely - a fókuszban Thomas Mannal - a szellemi szabadságot, az ember mivoltunkban való egyenlőséget, a fasizmus intézményesített barbárságával való szembenállást jelenítette meg. A fasizmussal való szembesülés, a gyermekként megélt irtózat - számos reflexióból kitűnően mély gyökere a szerző világlátásának, ami érzékennyé teszi a nacionalista kábulat minden jelére, az elvakult tömegek irracionalizmusára, a kollektív bünök 
feldolgozásának mulasztásaira, a tömegmészárlások más korokban is felbukkanó rémtetteire (a fekete rabszolgák behurcolásától a vietnami háborúig, csak a demokratikus Amerika történetére pillantva).

A szerző e kötetben is felidézi azt az 1989-es konfliktusát, amelynek kiindulópontja a kormányerővé váló MDF (Magyar Demokrata Fórum) antiszemita tendenciáit elmarasztaló The New York Times nyilatkozata volt, és amelynek következményeként az újabb akadémiai elnöki ciklusára vonatkozó jelölést elhárította, és Amerikába távozott. Közel hatvanévesen hozta meg e döntését, de visszatekintve, megbánni nem volt oka. Ezt tételesen leírja, de ezt illusztrálja a kötet egésze is: az eltelt harminc év élményanyagának színes gazdagsága, a mind teljesebb áttekintést tükröző történeti monográfiái, a legendás kaliforniai egyetem Los Angeles-i kampuszától a történészek nemzetközi szervezetében elfoglalt mértékadó pozícióinak puszta számbavétele. Abban bizonyosak lehetünk, hogy a gazdaság- és társadalompolitikában a 2010 óta végbement radikális hazai változások, az intézmények (beleértve az MTA) átalakítása és a kelet-nyugati orientáció egyensúlyjátéka akkor is kiváltotta volna a szerző fenntartásait, ha ezeket nem sok ezer kilométeres távolságban mérlegeli.

A szerző a korproblémákra a széles látókörủ gazdasági/történeti elemző szemszögéből tekint, eszköztárában ott a GDP, a realisztikus vásárlóerőparitás-számítás, az átlagok mögött rejtőzködő különbségek Gini-koefficiense. Így szemléli sokoldalúan az országok és - alkalmasint az ezeknél egyszerre finomabb és átfogóbb - régiók viszonyait. A népességcsökkenés és a túlnépesedés alakulását, a bevándorlás és kivándorlás ambivalens folyamatait. A jövedelmi viszonyokat, a középosztályt őrlő polarizálódást, s a társadalmi mobilitást lefékező, kasztszerü elkülönülés visszatérését. Az oktatás expanziójának mindezt keresztező tényeit. A technikai fejlődés újabb forradalmát, ami a korábbiakhoz hasonlóan a világlátás kulturális sokkjával jár - s ami szerinte a gazdasági folyamatoknál, válságos helyzeteknél közvetlenebbül és jobban magyarázza a világpolitika ezredfordulós nagy irányváltását.

A jelen friss fejleményeiben és a jövőbe vesző hosszú távú tendenciákban a felvilágosult realista szerző egyszerre lát biztató fejleményeket és súlyos veszélyforrásokat. A globalizáció folyamatának egyoldalú kárhoztatásával szemben a vitathatatlan társadalmi-gazdasági bajok fó forrásának a fejlett világban elhatalmasodó neoliberális gazdaságpolitikát, a benne leképeződő és általa indukált gazdasági-társadalmi polarizációt tartja. A globalizációval szembeállított nemzeti protekcionizmus, amely jobboldali és baloldali populizmusával tömegeket mozgósít, szerinte a gazdasági fejlődés ellen hat, és teljhatalomra törő lokális csoportok kiemelkedését és akár háborús ellentétet generál. Minden tökéletlenségével együtt, a különböző fejlettségű régiókat felölelő Európai Unió felépülése szerinte korszakos előrelépés, ennek külső (mindenekelőtt orosz) és belső, tagállami bomlasztása egyértelműen kárt okoz. Oroszországban a történeti el- 
maradottság és a csodálatos magaslatokba emelkedő kultúra ellentmondásának drámai példáját látja (és láttatja ismételten) a szerző, aki úgy véli, hogy az ismét a fegyverkezés útjára lépő volt szuperhatalom bekerítése politikai hiba, ami ráadásul az eltérő fejlettségű régiók integrálására vállalkozó Európai Uniót újabb, szinte megoldhatatlan terhekkel sújthatja. Nem nehéz ráeszmélni arra, hogy az itt futólag áttekintett szempontok alapján Berend Iván korszakos léptékben tekinti károsnak Trump amerikai elnök (és a hozzá csatlakozó Brexit-hívek, illetve az általa érvényesülni engedett Putyin-befolyás) történeti szerepét, ami destabilizálta a gazdasági fejlődést, a kialakult nemzetközi együttmüködést és szövetségi rendszereket, hozzájárult a társadalmi egyenlőtlenségek és feszültségek fokozódásához, $\mathrm{s}$ a békét minden értelemben veszélyezteti. Szerzőnk sem zárja ki, hogy míg a 20. század Amerika évszázada volt, a 21. Kínáé lehet, s ez is alapjaiban formálja át a világ képét.

A kötet mondanivalója tehát tépelődően súlyos, miközben egyes mozaikjainak bemutatása egyszerü, közvetlen hangvételü, nemegyszer derüs (nem véletlen, hogy a humor igénye és méltánylása felbukkan a legkülönbözőbb pontokon és szövegösszefüggésekben, írásmüvek, alkotók, élethelyzetek bemutatásakor). Ironikus játékosság maga a címadás is: az „Élj érdekes időkben” mint kínai átok, a kiszámíthatatlan, zaklatott, fenyegető történésekre és kilátásokra utal. Ugyanakkor megélt korunk a szó teljesebb értelmében is érdekes, hiszen nemes értékeket őriz, megküzdésre mozgósít, páratlan lehetőségeket is kínál - Berend Iván könyve ennek tanúbizonysága.

(Berend T. Iván: Élj érdekes idökben! Budapest: Éghajlat Könyvkiadó Kft., 2020, 595 o.)

Hunyady György 